\title{
SOME GARRISON AND COMMAND REGIMENTAL SERGEANT MAJORS AT THE CASTLE OF GOOD HOPE IN CAPE TOWN
}

\author{
Lt CDR W.M. Bisset*
}

Whilst the names of the officers who have commanded our commands and regiments have been recorded and are in many cases well known, the same cannot be said for all our garrison and regimental sergeant majors. Unlike unit commanders, regimental sergeant majors do not sign a handing over certificate on appointment, so it is often very difficult to establish who the successive regimental sergeant majors of some of our units where. ${ }^{1}$ However, by good fortune and some guesswork, which yielded unexpectedly good results it has been possible to fill another gap in our knowledge about some of those who have served at the Castle of Good Hope

Two of the British garrison sergeant majors at the Castle have been traced and both ended their days in Cape Town. Garrison Sergeant Major David Mackay came to the Cape of Good Hope as a quartermaster sergeant in the 98th Regiment (2nd Battalion the North Staffordshire Regiment) in March 1825, was appointed Garrison Sergeant Major on 25 December 1829 and held this post until 21 March 1859.

A tribute published on 7 January 1864 after his death at the age of 70 years gives a vivid picture of this remarkable soldier:

'In his military capacity the Sergeant-Major enjoyed the confidence and respect of all who came in contact with him, whether of the highest rank or the lowest. The officers in command considered him as their right-hand man, and the humblest private in the place felt that the venerable Sergeant-Major was the soldiers' finest friend. He was in fact quite a garrison institution in himself, and when Prince Alfred was here three years ago, Sir George Grey took special care that, amongst the officers particularly introduced to him, should be the respected veterans Inglesby and Mackay.

Repeatedly the Sergeant-Major was offered a commission, but as frequently declined it; a few years ago, however, he was offered and ac- cepted a special good service pension from the Queen. Apart from his professional duties Sergeant-Major Mackay was one of the most esteemed and estemable men in the community. As an elder of the Scottish church, as president of the Temperance Society and in a score of other capacities besides, he was ever ready to promote the good of his fellow men:- while whatever he did was done with such cheerfulness and good-will, that the value and efficacy of it became doubly enhanced, and now that the good old man is gone, we are sure that very many of high and low, rich and poor alike will sadly miss his venerable and form and kindly smiling face'?

On the morning of Garrison Sergeant Major Mackay's funeral the Castle flag was flown at half mast. This honour had never previously been granted to any NCO. At about 1615 hours the cortege started on its journey from the Castle to the Scotch burying ground led by the firing party with arms reversed. The band playing the Dead March in Saul and Beethoven's Italian March and the hearse drawn by four black horses followed. On the coffin were the Castle flag and some of Mr Mackay's accoutrements. Behind the hearse marched officers and NCO's followed by relatives and friends in three carriages. Then followed the Royal Artillery, Cape Mounted Riflemen, Commissariat and Cape Volunteers (including Cavalry, Artillery, Royal Rifles, Scottish Corps and Engineers), the 11th Regiment (The Devonshire Regiment), the Teetotallees and miscellaneous mourners some of whom were in carriages and cabs. ${ }^{3}$

In a letter of sympathy to Mr Mackay's family, Genl Sir Josias Cloete, one of the Groot Constantia family who had served in the British Army wrote: '. . . in all justice ... during the long course of my Military Service, I cannot recall to my recollection his equal in combining all the high qualities of a soldier and a Christian.' ${ }^{4}$ 
W.D.H. Beatie joined the Royal Artillery in 1872 , was appointed Garrison Sergeant Major at the Castle in 1893 and acted as Chief Clark to successive Chief Staff Officers of the Volunteer regiments in the Cape Peninsula. During the South African War of 1899-1902 he was commissioned in the Scottish Horse. He later joined the Union Defence Forces in which he served as a Staff Officer in the Union during World War I and was promoted to the rank of Captain. He retired in 1920. Captain Beattie's career draws attention to the former British Garrison's link with the Union Defence Forces and it would be interesting to discover how many similar transfers there were. Captain Beattie's medals and presentation cane have been donated to the SA Defence Force by his family and are now on display in the Military Museum at the Castle.

According to his newspaper obituary WOI John Joseph Sheedy who was born in Ireland and came to South Africa as a gunner in 77th Battery Royal Artillery in 1899 was 'RSM to the Royal Artillery Garrison at Cape Town Castle but was retired by the British Army in 1914'. Union Defence Forces Archives confirm that WOI Sheedy was discharged from the Royal Artillery on 25 February 1914 but gave his rank as Battery Sergeant Major.

On 26 February 1914 he enlisted in the Permanent Force (1st SAMR) as a Battery Sergeant Major. After service in the German South West African Campaign he was appointed Acting Brigade Sergeant Major (Artillery) on 1 December 1915. He was posted to the SA Permanent Garrison Artillery as RSM on 1 February 1922 but it is not certain whether he was in fact also Garrison RSM. His last nine years in uniform were spent at the Castle and he retired in 1931.

WOI John William Riley was appointed Garrison Sergeant Major, Cape Town on 1 September 1923 and was transferred to QuartermasterGeneral Pretoria on 1 February 1930. He had served in the 2nd Battalion Scottish Rifles from 15 August 1895 until 15 August 1903 and served during the South African War from 1901-1902. On 13 January 1905 he joined the Transvaal

Volunteers Permanent Staff and remained in uniform until his death on 22 October 1934. During the First World War he was granted an Imperial Army commission and promoted to the acting rank of Captain. For his service in France where he was wounded in action he was mentioned in a War Office Communique.
WOI Albertus Johannes Viljoen succeeded WOI Riley as Garrison Sergeant Major on 30 January 1930 and was transfered to No 5 Military District in Pretoria on 31 May 1933. WOI Viljoen served in the 1914 Strike, Rebellion, German South West African and German East African Campaigns and the 1922 Strike. From June 1916 until 17 April 1917 he held a temporary Imperial Army Commission.

WOI Cornelius Ritchie van Niekerk was appointed Garrison Sergeant Major, Cape Town on 31 May 1933 and held the post until 31 March 1937. WOI van Niekerk enlisted in the Permanent Force Staff on 1 October 1913 and was mentioned in dispatches for service in the German South West African Campaign. During World War II he served as an instructor in the Union and retired on 23 January 1945.

The group photograph of the Headquarters Staff, Cape Peninsula Garrison in August 1925 which illustrates this article is reproduced by kind permission of Akkersdyk Studios, Cape Town. In the second row are Sergeant Majors C.R. van Niekerk (third from the left) and J.W. Riley (sixth from the left).

\section{HEADQUARTERS STAFF, CAPE PENINSULA GARRISON (AKKERSDYK - CAPE TOWN) AUGUST, 1925}

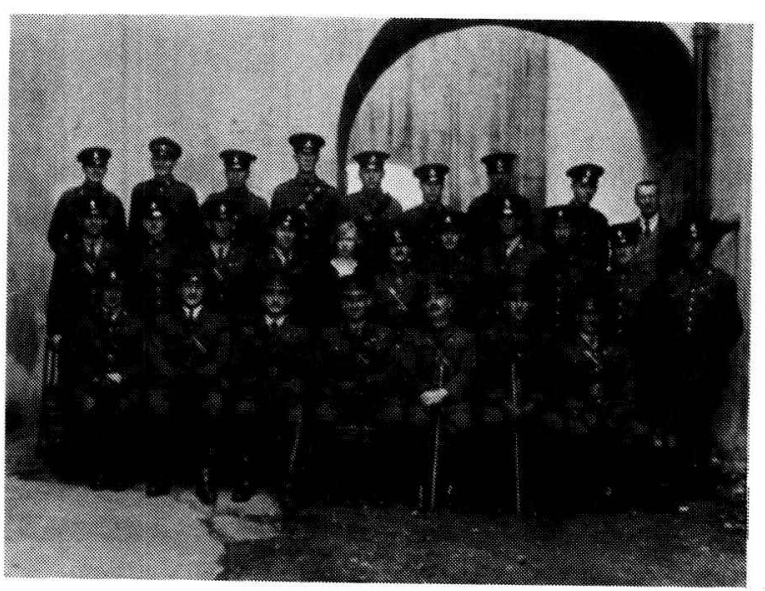

BACK ROW: Cpl W.D. Nelson, Pte C. Johnson, CpI N.H. Havenga. Lance-Bdr P.J. van Schalkwyk. Bdr G.H.H. Kapp. Lance-Bdr I.J. Vermeulen, Lance-Bdr J.J. Seaman, Act-Sgt Owens. Mr C.J. de Smidt.

SECOND ROW: Sgt-Maj P.J. Redelinghuys, SGT S.A. Johnson, SGT-Maj-Instr C.R. van Niekerk, ACt-Sgt E.W. Pinnock, Miss E. Stuckenberg, Sgt-Maj J.W. Riley, Pte A.E. Savage, Sgt-Maj-Instr J.K. Kirk, Sgt H. Wessels, Sgt W. Tolmie, Staff-Sgt-Instr W.E. Jorisen.

SEATED: Lt H.D. White, Capt G.M. Upton, Lt-Col F.G. Harvey, CBE, DSO., Brig-General W.E.C. Tanner, CB, CMG, DSO., Col F.C. Willmot. Capt P. de Waal, Lt C.J. Hearn, MC. 


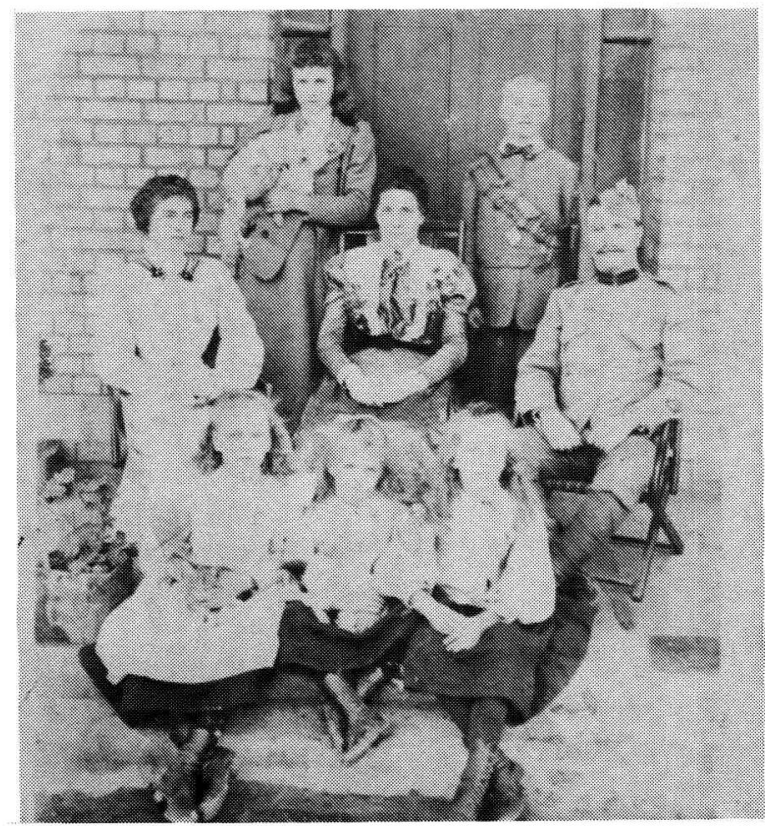

Garrison Sergeant Major W.D.H. Beattie with his wife and family

In recent years the present WP Command RSM, as the Garrison Sergeant Major's post is now known, WOI W.J. Nell, has gone to endless trouble to assemble a collection of photgraphs of his predecessors and to discover their nicknames. The Akkersdyk photograph in the Military
Museum collection provided the clue which led to the discovery of two more Garrison Sergeant Majors and their photographs.

The brief details of some of the early Garrison Sergeant Majors at the Castle published above underline the importance of keeping alive the memory of such men who truly are the backbone of any army and it is hoped that in due course it will be possible to complete this impressive roll. At least one Garrison/Command Sergeant Major, WOI J.P. van Eeden, PMM, has acted as such after his retirement.

The writer wishes to thank Akkersdyk Studios, Cape Town, Military Information Bureau, SADF and in particular Col J.A. Combrinck, WOI W.J. Nell and the families of Garrison Sergeant Majors D. Mackay and W.D.H. Beattie for their invaluable help without which this article could not have been written.

(1) Information supplied by SADF Archives

(2) Press cutting

(3) Press cutting

(4) Letter from Genl Sir Josias Cloete dd 11 April 1864

*Lt Cdr W.M. Bisset is SO SA Naval Museums.

\section{ANNEXURE 'A'}

\section{SOME GARRISON/COMMAND RSM'S AT THE CASTLE OF GOOD HOPE}

\begin{tabular}{|c|c|c|c|c|}
\hline Number & Name & Nickname & $\begin{array}{l}\text { Regiment or } \\
\text { Corps }\end{array}$ & Dates \\
\hline & D. Mackay & & 98th Regt & 25 Dec $1829-21$ Mar 1859 \\
\hline & W.D.H. Beattie & & $\begin{array}{l}\text { Corps of } \\
\text { Military } \\
\text { Staff Clerks }\end{array}$ & 1893(?) - 5 Oct 1900(?) \\
\hline $1646^{\star}$ & J.J. Sheedy & & SAPGA & 1 Feb 1922(?) \\
\hline 1003 & J.W. Riley & & SAIC & 1 Sep 1923 - 29 Jan 1930 \\
\hline 1033 & A.J. Viljoen & & SAIC & 30 Jan 1930 - 30 May 1933 \\
\hline \multirow[t]{3}{*}{1032} & C.R. van Niekerk & & SAIC & 31 May 1933 - 31 Mar 1937 \\
\hline & L.A.J. Botha & Staalbaard & & 1 Apr $1937-1941$ \\
\hline & M. Maritz & Manie & SAA & $1941-1945$ \\
\hline P2654 & E. Troskie & Manie & & $1946-1959$ \\
\hline \multirow[t]{4}{*}{ P3659 } & J.M. Schmidt & Small Hops & ASC & 1960 - 31 Jan 1965 \\
\hline & F.G. de Beer, SM & Frikkie & $\operatorname{SAA}(A A)$ & 1 Feb 1965 - 30 Nov 1968 \\
\hline & M.J. Louw & Max & SAIC & 1 Dec 1968 - 28 Feb 1971 \\
\hline & J.P. van Eeden, PMM & Spuds & SAIC & 1 Mar 1971 - 30 Oct 1974 \\
\hline 05079736PE & W.J. Nell & Bill & $\mathrm{SAA}(\mathrm{AA})$ & 1 Nov 1974 - still serving \\
\hline
\end{tabular}

*As stated in this article it is not certain whether this RSM who served at the Castle held the post of Garrison Sergeant Major. 